\title{
Performance of Gaillardia Genotypes under Eastern Vidarbha Zone
}

\author{
Shalini Badge ${ }^{1 *}$, Maya Raut ${ }^{2}$ and G. B. Ganvir ${ }^{3}$ \\ ${ }^{1}$ Department of Horticulture, Agriculture Research Station, Sonapur-Gadchiroli, India \\ ${ }^{2}$ (SSAC), College of Agri. Sonapur-Gadchirooli, India \\ ${ }^{3}$ Agriculture Research Station, Sonapur-Gadchiroli, India \\ *Corresponding author
}

Keywords

Gaillardia,

Genotypes, Growth, Flowering, Yield, Quality

\section{Article Info}

Accepted:

07 March 2020

Available Online:

10 April 2020

\section{A B S T R A C T}

The present investigation was carried out to assess the performance of ten Gaillardia pulchella foug. Genotypes ( SG 1, SG 2, SG -3, SG- 4, SG -5, SG - 6, SG -7, SG -8, SG -9 and SG - 10) for their growth, flowering, yield and quality characters. Significant differences were observed for all parameters studied. The results revealed that maximum height of plant $(72.33 \mathrm{~cm})$, branches plant ${ }^{-1}$ (17.66), plant spread N-S \& E-W $(64.99 \mathrm{~cm})$ was recorded in genotype in in SG-11, fresh weight $(1426.33 \mathrm{~g})$ and dry weight $(221.33 \mathrm{~g})$ was recorded in genotype $\mathrm{SG}-2$. As regards flowering parameters viz., days to first flower bud initiation (48.66 days) and days to 50 per cent flowering (57.53 days) were recorded early in genotype SG -7. As regards quality parameters $\mathrm{i}$. e. diameter of flower $(7.72 \mathrm{~g})$ recorded maximum in genotypes $\mathrm{SG}-3$ and weight of flowers $(4.77 \mathrm{~g})$ in genotypes SG-7. Yield parameters viz., number of flower per plant (60.67) was maximum in genotype SG-4, yield of flower per plant (288.02 g) and ha $(21.87 \mathrm{t})$ in genotype 5 .

\section{Introduction}

Gaillardia (Gaillardia pulchella Foug.) popularly known as 'Blanket Flower' or Fire Wheel, belong to the family Asteraceae and is native to Central and Western United States, having the basic chromosome number $\mathrm{X}=18$ and $2 \mathrm{n}=36$ (Srivastava and Kandpal, 2006). There are about twenty eight species reported in the genus Gaillardia, but only two of them viz. Gaillardia pulchella (annual) and Gaillardia aristica (perennial) are under cultivation. The plants possess brilliant daisylike flowers with single, double and semi double forms (Cox and Klett, 1984). Flowers are small and numerous, born solitary at each node, showy heads are 4 to $6 \mathrm{~cm}$ in diameter having a long hairy stalk. Individual flowers 
in a capitulam are called florets. As a member of Asteraceae (Compositae) it has both ray (Pistillate) and disc florets (Hermaphrodite). The crop produce flowers in a wide range of colors such as yellow, orange, cream, scarlet, bronze, brick red, red tipped and red with yellow tipped and can be grown all around the year. Gaillardia is a perfect plant for flower beds, borders and corners. It is also used for garlands, bouquets and as loose flower.

Nowadays, gaillardia has gained importance for its profuse and long duration flowering habit. It is one of the hardiest annuals that can be grown in a variety of soils and under varied climatic conditions. Present investigations were carried out to assess ten gaillardia genotypes for growth, flowering, yield and quality parameters to select suitable accession for further exploitation.

\section{Materials and Methods}

An experiment entitled "Performance of different gaillardia genotypes in respect of growth, flowering, and yield parameters" was carried out at the farm of Horticulture Section, College of Agriculture, Nagpur during September, 2018 to March, 2019. Experiment was laid out in randomized block design with three replications and ten genotypes as treatments. The genotypes consists of viz., SG-1, SG-2, SG-3, SG-4, SG5, SG-6, SG-7, SG-8, SG-9 and SG-10. The experimental land was ploughed once, crosswise harrowing was done for clod crushing and soil was brought into the fine tilth. At the time of land preparation, well rotten FYM @ 10 tonnes $\mathrm{ha}^{-1}$ was mixed uniformly in the soil before last harrowing. The field was laid out with flat beds of the dimensions of $2.25 \mathrm{~m}$ $\mathrm{X} 1.80 \mathrm{~m}$.

The raised beds of $7 \mathrm{~m}$ length and $1 \mathrm{~m}$ width and $15 \mathrm{~cm}$ height were prepared for raising the seedlings of Gaillardia. The seeds were sown on raised beds in the line by keeping 8 $\mathrm{cm}$ distances within two lines. Immediately after seed sowing nursery beds were irrigated with the help of water can. Regular watering was given in the morning till the seedlings were ready for transplanting. Seedlings were allowed to grow in the nursery beds up to 30 days and then transplanting was done. Healthy seedlings were transplanted at a spacing of $45 \mathrm{~cm} \times 30 \mathrm{~cm}$ distance in ridges and furrow layout. The recommended dose of fertilizer (100: 50: $50 \mathrm{~kg} \mathrm{NPK} \mathrm{ha}{ }^{-1}$ ) was applied to all the plots in the form of urea, single super phosphate and muriate of potash. Out of this, full dose of phosphorous and potassium and $1 / 2$ dose of nitrogen were applied at the time of transplanting. The remaining dose of nitrogen was applied in two split doses, first dose was given at 30 days and second dose was given at 45 days after transplanting. Observations were recorded on growth parameters viz., height of plant, number of branches plant-1, plant spread, leaf area and flowering parameters viz., days to first flower bud initiation, days to opening of flower, days to 50 per cent flowering, days to first harvesting, flowering span and yield hectare-1 and growth parameters viz., weight of flower, shelf life and collected data were statistically analyzed as per method suggested by Panse and Sukhatme (1978).

\section{Results and Discussion}

Data from table 1 revealed that, at the stage of 90 days after transplanting, significantly maximum plant height $(72.33 \mathrm{~cm})$ was recorded in genotype SG 10 followed by the genotypes SG -2 and $S G-1$. The minimum plant height $(62.33 \mathrm{~cm})$ was recorded in genotype SG- 6. Significantly maximum number of branches plant ${ }^{-1}$ (17.66) was recorded in genotype SG-10 followed by genotypes SG-1, SG- 2 and SG-5. Whereas, significantly minimum number of branches plant $^{-1}$ (14.17) was recorded in SG -9. The 
plant spread (E-W and N-S) $(61.66 \mathrm{~cm})$ was recorded significantly maximum in SG-10 $(68.66 \mathrm{~cm})$ over the rest of the genotypes. Whereas, minimum plant spread $(61.66 \mathrm{~cm})$ was recorded in SG-5. The genotype SG-2 had significantly maximum stem diameter $(1.21 \mathrm{~cm})$ which was at par with SG -10, SG 9, SG -1 .

These results might due to the differences among the genotypes for height of plant and numbers of branches plant ${ }^{-1}$, diameter of plant might be due to the differential genetic makeup and varied growth rate among the genotypes of gaillardia. Similar results were recorded by Bharathi and Jawaharlal (2014). They revealed that, highest plant height was recorded in cv. Dharmapuri Local in marigold. Kumar et al., (2018) reported that maximum plant height was recorded in 'Genotype-3 and more number of branches were recorded in genotype 2 in gaillardia. Agale et al., (2017) recorded maximum plant spread in genotype MG -9 in gaillardia.

Significantly maximum fresh weight (1426.33 g) and dry weight (221.46 g) was recorded in genotypes $\mathrm{SG}-2$ as compared to other genotypes. However, minimum fresh weight $(738.13 \mathrm{~g})$ and dry weight (123.66 g) was recorded in the genotypes SG-5.

The variation in plant spread and fresh and dry weight of plants of gaillardia genotypes might be attributed due to the genetic differences of the genotypes used as the most of the characters are governed by the genetic makeup of the plant. Narsude et al., (2010) reported that, maximum plant height and plant spread was recorded in cv. Pakharsangavi Local. Kumar et al., (2018) reported that maximum fresh and dry weight was recorded in 'Genotype-2 in gaillardia. The results also find support from findings of Agale and Dawane (2016), Bhaskarwar et al., (2016) and Tamut and Kulkarni (2013).

\section{Flowering parameters}

Data from table 2 revealed that, early flower bud initiation was recorded in genotype SG07 (48.66 days) and days to $50 \%$ flowering (57.53 days) were observed in genotypes 07. However, delayed flower bud initiation (58.66 days) and days to $50 \%$ flowering (67.87 days) were recorded in SG -01. The different period required for first flower bud initiation and days to opening of flower in gaillardia genotypes might be due varied growth rate and their genetic makeup. The days to $50 \%$ flowering and days to first harvesting are might be due to earliness in first flower bud initiation and days to opening of flower. These results are in close agreement with the results of Singh et al., (2003). Arulmani et al., (2015) reported that, minimum days taken for first flower appearance and days taken for 50 per cent flowering were observed in gaillardia cv. DGC-2. Agale et al., (2018) recorded early flowering and $50 \%$ flowering in genotypes 11 in gaillardia. Similar finding also reported by Bhaskarwar et al., (2016) and Girange et al., (2016) in gaillardia.

\section{Quality parameter}

Data from table 1 revealed that, significantly maximum weight of flowers was recorded in SG-07 (4.77 g) which was at par with genotypes, SG-03, SG-10, SG-06 SG-02 and SG-9. The minimum weight flower was produced by genotype SG -04 (3.77 g). The variation in average weight of flower might be due to the variation in genetic variation of each genotypes. Bhaskarwar et al., (2016) recorded maximum weight of flower is recorded in genotypes Local -6 in gaillardia. Agale et al., (2017) recorded maximum weight of flower in genotype MG 6 in gaillardia. Similar results were also reported by Similar variation in weight of flower was also reported by Narsude et al., (2010) in African marigold. 
Table.1 Vegetative growth parameters as influenced by different genotypes of gaillardia

\begin{tabular}{|l|c|c|c|c|c|c|}
\hline $\begin{array}{l}\text { Name of } \\
\text { genotypes }\end{array}$ & $\begin{array}{c}\text { Plant height } \\
\text { (cm) }\end{array}$ & $\begin{array}{c}\text { Number of } \\
\text { primary } \\
\text { branches }\end{array}$ & $\begin{array}{c}\text { Plant } \\
\text { spread } \\
\text { (cm) }\end{array}$ & $\begin{array}{c}\text { Diameter of } \\
\text { plant } \\
(\mathbf{c m})\end{array}$ & $\begin{array}{c}\text { Plant fresh } \\
\text { weight }(\mathbf{g})\end{array}$ & $\begin{array}{c}\text { Plant dry } \\
\text { weight } \\
\text { (g) }\end{array}$ \\
\hline SG- 1 & 69.33 & 16.66 & 66.33 & 1.17 & 858.66 & 137.66 \\
\hline SG - 2 & 69.66 & 16.66 & 65.66 & 1.21 & 1426.33 & 221.46 \\
\hline SG - 3 & 66.33 & 15.33 & 66.45 & 0.96 & 1112.66 & 213.33 \\
\hline SG - 5 & 67.33 & 16.33 & 61.66 & 1.11 & 852.33 & 118.47 \\
\hline SG - 6 & 62.66 & 14.33 & 63.33 & 1.12 & 1001.66 & 200.33 \\
\hline SG - 7 & 64.33 & 15.86 & 63.33 & 1.08 & 738.13 & 123.66 \\
\hline SG - 8 & 65.33 & 15.73 & 66.33 & 1.15 & 1064.33 & 187.33 \\
\hline SG - 9 & 66.66 & 14.17 & 65.33 & 1.17 & 1157.33 & 170.46 \\
\hline SG - 10 & 72.33 & 17.66 & 68.66 & 1.17 & 803.67 & 187.66 \\
\hline SEm \pm & 0.70 & 0.31 & 0.62 & 0.29 & 29.30 & 3.74 \\
\hline CD 5\% & 2.06 & 0.93 & 1.81 & 0.86 & 85.94 & 10.98 \\
\hline
\end{tabular}

Table.2 Flowering and yield parameters as influenced by different genotypes of gaillardia

\begin{tabular}{|c|c|c|c|c|c|c|c|}
\hline $\begin{array}{l}\text { Name of } \\
\text { genotypes }\end{array}$ & $\begin{array}{l}\text { days taken } \\
\text { to first } \\
\text { flower bud } \\
\text { initiation } \\
\text { (days) }\end{array}$ & $\begin{array}{l}\text { Days taken } \\
\text { to } 50 \text { per } \\
\text { cent } \\
\text { flowering } \\
\text { (days) }\end{array}$ & $\begin{array}{l}\text { Flower } \\
\text { diameter } \\
\quad(\mathbf{c m})\end{array}$ & $\begin{array}{c}\text { Weight } \\
\text { of } \\
\text { flowers } \\
\text { (g) }\end{array}$ & $\begin{array}{c}\text { Number of } \\
\text { flowers } \\
\text { per plant }\end{array}$ & $\begin{array}{l}\text { Weight } \\
\text { of } \\
\text { flowers } \\
\text { per plant } \\
\text { (g) }\end{array}$ & $\begin{array}{l}\text { flower } \\
\text { yield } \\
\text { per } \\
\text { hectare } \\
\text { (t) }\end{array}$ \\
\hline SG- 1 & 58.66 & 67.87 & 5.10 & 3.86 & 58.27 & 224.92 & 16.64 \\
\hline SG - 2 & 52.00 & 64.07 & 6.31 & 4.20 & 58.47 & 245.54 & 18.17 \\
\hline SG - 3 & 48.33 & 59.93 & 7.72 & 4.61 & 55.93 & 257.83 & 19.08 \\
\hline SG - 4 & 55.33 & 64.03 & 7.06 & 3.77 & 60.67 & 228.72 & 16.93 \\
\hline SG - 5 & 50.66 & 65.40 & 6.67 & 3.89 & 58.90 & 288.02 & 21.87 \\
\hline SG - 6 & 51.33 & 62.47 & 6.05 & 4.24 & 60.10 & 254.82 & 18.86 \\
\hline SG - 7 & 48.66 & 57.53 & 5.37 & 4.77 & 60.28 & 287.53 & 21.28 \\
\hline SG - 8 & 58.33 & 70.66 & 4.43 & 4.01 & 59.74 & 239.55 & 17.72 \\
\hline SG - 9 & 55.66 & 68.33 & 5.74 & 4.12 & 57.41 & 236.52 & 17.50 \\
\hline SG - 10 & 56.00 & 70.66 & 5.83 & 4.46 & 60.39 & 269.33 & 19.92 \\
\hline SE m \pm & 0.55 & 0.69 & 0.11 & 0.60 & 3.46 & 11.30 & 1.27 \\
\hline $\mathrm{CD}$ at $5 \%$ & 1.63 & 2.03 & 0.34 & 1.78 & 10.15 & 33.90 & 3.87 \\
\hline
\end{tabular}

Data from table 1 revealed that, significantly maximum diameter of flowers was recorded in SG-03 $(7.72 \mathrm{~cm})$ which was at par with SG-07, SG-10, SG-06 and SG-08. The minimum diameter of flowers was produced by genotype $\mathrm{SG}-08(4.43 \mathrm{~cm})$. This is due to the genetic make of different genotypes. Swaroop et al., (2004) evaluated four varieties of China aster and noted that the diameter of flower was maximum in Poornima, Agale et al., (2017) recorded maximum diameter of flower in genotype $\mathrm{MG}$ 6 in gaillardia. Kumar et al., (2018) recorded maximum diameter of flower is recorded in genotypes 11 in gaillardia. 


\section{Yield parameter}

Data from table 1 revealed that, significantly maximum number of flowers plant ${ }^{-1}$ was recorded in SG-04 (60.67) which was at par with genotypes SG-7, SG-10, SG-06 and SG 8. The minimum number of flowers plant ${ }^{-1}$ (55.93) was produced by genotype SG-03. Significantly maximum yield of flowers plant $^{-1}(288.02 \mathrm{~g})$ and hectare ${ }^{-1}(21.87 \mathrm{t})$ was recorded in SG-05 which was at par with genotypes SG-7, SG-10, SG-06 and SG -03. The minimum yield of flowers plant ${ }^{-1}(224.92$ g) hectare $^{-1}(16.64$ t) was produced by genotype SG-01. The estimated flower yield per hectare in various genotypes was closely associated with fresh flower weight, number of flower per plant and number of branches per plant increased the flower yield per hectare. The variation in flower weight is due to increased flower size and presence of fairly more number of ray florets and thickness of ray florets (Swaroop et al., 2008) in chrysanthemum. Several findings also reported by Tamut and Kulkarni (2013) in gaillardia.

Similar results were also reported by Bhaskarwar et al., (2016) and Girange et al., (2018) in gaillardia. Agale et al., (2017) recorded maximum yield in genotypes MG -9 in gaillardia. Kumar et al., (2018) recorded maximum flower yield in genotypes 11 in gaillardia.

On the basis of results of the present experiment the following conclusion may be drawn. Under the agro-climatic conditions of East zone of Vidarbha, out of 10 genotypes tested. The maximum plant height and number of primary branches were recorded in 'Genotype SG -10' and 'Genotype SG -01' respectively. The 'Genotype SG 5- was found superior in characters, number of flowers per plant, weight of flowers per plant and flower yield per hectare.

\section{References}

Agale, M.G. and Dawane, P.T. (2016). Evaluation of different genotypes of gaillardia for growth and yield of flowers. Indian Horti. J., 6(1): 102-105.

Agale, M.G., Patil, B.B. and Kalamkar, R. B. 2017. Evaluation of Different Genotypes of Gaillardia for Vegetative, Reproductive and Quality of Flower Characters. Trends in Biosciences 10(40): 8467-8473

Arulmani, N., S. Y. Chandrashekar, S. Y. Ramesha and S. K. Natraj, 2015. Evaluation of gaillardia (Gaillardia pulchella foug.) genotypes for growth and flowering under hill zone of Karnataka.Ph. D. thesis.College of Horticulture, Mudigere, Karnataka, India.

Bharati, T. U., and M. Jawaharlal, 2014.Evaluation of marigold (Tagetes erecta.L.) genotypes for growth and flower yield under Coimbatore condition. Tren. In. Biosci. 7(16): 21972201.

Bhaskarwar, A.C., Jadhav, G.N., Ghube, N., Tayade, M.M. and Patekar, T.R.(2016).Performance of different gaillardia genotypes in respect of growth, flowering, quality and yield parameters.Int.J. Res. Biosci. Agri. Tech., 4(2): 7-10.

Cox, R.A. and Klett, J. E. (1984).Evaluation of some indigenous western plants for xeric landscape. Horti. Sci., 19: 856858.

Girange, R.R., Charjan, S.U., Jadhav, G.N., Bhaskarwar, A.C., Ghube N.N. and Lambat, A.P. (2016). Evaluation of different genotypes of gaillardia for growth, flowering and yield parameters. Int. J. Agri. Sci. Res., 6(6): 301-306.

Narsude, P. B., A. S. Kadam and V. K. Patil, 2010. Studies on the growth and yield attributes of African marigold (Tagete 
serecta L.) genotypes under Marathwada condition. .Asian. J. Hort. 5(2): 284-286.

Rahul Kumar Byadwal, Ashutosh Mishra, Apoorva Palled and Jitendra Bunkar (2018). Evaluation of different genotypes of gaillardia (Gaillardia pulchella Foug.) under Jhalawar condition. J. Environ. Sci., Toxicology and Food Technology. 12(10):56-59

Singh, D., Sen, N.L. and Sindhu S.S. 2003. Evaluation of Marigold Germplasm under semi-arid condition of Rajasthan. Haryana J. Hort. Sci. 32 (3-4): 206- 209
Gaillardia. In: S.K. Bhattacharjee (edi.), Advances in Ornamental Horticulture. I(1): 294-304

Swaroop, K., Prasad, K.V. and Raju, D.V.S. (2008). Evaluation of chrysanthemum (Dendranthema grandiflora Tzveleve.) germplasm in winter season under Delhi conditions. J. Ornam. Horti., 11(1): 5861.

Tamut, O. and Kulkarni, S.B (2013). Characterization and evaluation of germplasm of gaillardia (Gaillardia pulchella Foug.). J. Flori. \&Land.,1(1): 44-49.

Srivastava, R. and Kandpal, K. (2006).

\section{How to cite this article:}

Shalini Badge, Maya Raut and Ganvir. G. B. 2020. Performance of Gaillardia Genotypes under Eastern Vidarbha Zone. Int.J.Curr.Microbiol.App.Sci. 9(04): 664-669. doi: https://doi.org/10.20546/ijcmas.2020.904.080 